\title{
Development of the Faith Movement in the Czech Republic
}

\author{
Tereza Halasová
}

https://doi.org/10.14712/25704893.2017.1

\begin{abstract}
This article deals with the development of the Faith Movement in the Czech Republic. Firstly, the Pentecostal Movement will be introduced on a general level and further on the specifics of the teachings of the Faith Movement will be described. The main part of the paper examines the development of several independent fellowships in the Czech Republic that emerged through the mission of the Faith Movement. The following seven newly established free churches will be introduced: the Word of Life Church; the New Hope Church; the Church of Living God; the Faith Church; the New Life Church; the Oasis Church; and the Centre of Triumphal Faith. Some of these fellowships underwent significant changes and became closer to the Evangelical Movement. This paper will analyze the processes through which these fellowships have changed their attitudes, mainly through abandoning some of the more distinctive features of the Faith movement and through their willingness to cooperate with other Evangelical churches.
\end{abstract}

Keywords: Pentecostalism, Faith Movement, Free churches, development, ecumenism

\begin{abstract}
Abstrakt: Tento článek se zabývá vývojem hnutí víry v České republice. Nejdř́ve čtenáře seznamuje s obecnou charakteristikou pentekostálního hnutí a se specifickými důrazy hnutí víry. Následující část je věnována popisu vývoje jednotlivých církevních společenství, která v České republice díky misii tohoto hnutí vznikla. Jedná se o Církev Slovo života, Církev Nová naděje, Církev živého Boha, Církev víry, Církev Nový život, Církev Oáza a Triumfální centrum víry. Některá z těchto společenství prošla významnou změnou a začala se více přibližovat křestanským společenstvím evangelikálního typu. Tento posun je zřetelný zvláště $\mathrm{v}$ opouštění některých výrazných doktrín učení hnutí víry a ochotě ke spolupráci s jinými evangelikálními církvemi.
\end{abstract}

Klíčová slova: Pentekostální hnutí, hnutí víry, nezávislé církevní společenství, vývoj, ekumenická spolupráce

Received: 1 December 2015, Accepted: 25 March 2016

Published online: 26 June 2017

Mgr. et Mgr. Tereza Halasová, Ph.D. student, Department of Religious Studies, Protestant Theological Faculty of Charles University.

E-mail: Tereza.Halasova@email.cz

(c) 2016 Author. This is an open-access article distributed under the terms of the Creative Commons Attribution License (http://creativecommons.org/licenses/by/4.0), which permits unrestricted use, distribution, and reproduction in any medium, provided the original author and source are credited. 
Typically, the Faith Movement has strong objections to the ecumenical openness of Evangelical churches. However, some of these fellowships are obviously undergoing radical change and, as a result, they are endeavouring to conduct successful missions in their communities.

Firstly, the Pentecostal Movement will be introduced on a general level. Later, the Faith Movement will be classified.

\section{(1) The Pentecostal Movement and its development and classification of the Faith Movement}

The Pentecostal Movement is the fastest growing missionary movement in the world, with strong emphasis on the Holy Spirit, the third person of the Trinity, and his gifts.

This movement is unique in the history of Christianity because of its rapid growth in numbers since its founding at the beginning of the 20 th century. Today the movement encompasses almost a hundred million followers. ${ }^{1}$

One of the typical features of this movement is its remarkable adaptability to local conditions, which is why it is possible to find great diversity and a huge variety of branches within this movement. These branches may vary greatly, but they still have some features typical to the Pentecostal Movement, which is how they can easily be distinguished from other streams within the Christian tradition.

Walter Hollenweger, the founding father of academic research into Pentecostalism, mentions three distinct forms in global context:

\section{Classical Pentecostals}

2. Charismatic Renewal Movements

3. Pentecostal or "Pentecostal-like" independent churches in the Majority World. ${ }^{2}$

In the Czech Republic, the Apostolic Church represents Classical Pentecostals. The Charismatic Renewal Movement within traditional churches is represented by fellowships that are part of the Catholic Charismatic Renewal. The fellowships emerging from, and developed in, traditional churches can also be counted in this category. They have often separated from traditional churches because they displayed features typical to the Charismatic Renewal Movement. ${ }^{3}$ Other Pentecostal fellowships belong to the third above-mentioned group - Pentecostal or "Pentecostal-like"

A. Anderson, An Introduction to Pentecostalism, Cambridge: Cambridge University Press 2007, p. 1. More in: "Global Statistics", in S. M. Burgess and E. M. VAN DER MaAs (eds.), The New Dictionary of Pentecostal and Charismatic Movements, revised and expanded edition, Grand Rapids: Zondervan 2002, p. 284-302.

2 Walter J. Hollenweger, Pentecostalism: Origins and Developments Worldwide, Peabody: Hendrickson 1997, p. 1; ANDERSON, An Introduction to Pentecostalism, p. 13.

3 In the Czech Republic, one of the churches that developed in this manner was for example the Christian Fellowship, whose founder Dan Drápal was a vicar of the Evangelical Church of Czech Brethren. 
independent churches, sometimes called the Third wave. ${ }^{4}$ The features that distinguish them from the first two forms are as follows:

1. They are the biggest and most diverse group within the large Pentecostal family.

2. They have no traditional Pentecostal or Charismatic denominational connections, but they share the same experience attributed to the Holy Spirit.

3. Many of them have been influenced by the Faith Movement. That is why they have constituted themselves as independent churches, although they were originally traditional churches.

These churches are also called "post-denominationalist" and "neo-apostolic". They are clearly distinct from the Classical Pentecostals and the Charismatic Renewal Movement, but they share with them an emphasis on the power of the Holy Spirit. These fellowships are also the most frequently criticized, usually for their questionable theological teachings, which is also the reason why Classical Pentecostal churches and fellowships, which developed from the Charismatic Renewal Movement, clearly dissociate themselves from them. ${ }^{6}$

\section{(2) Characteristic features of the Faith Movement}

The Faith Movement ${ }^{7}$ stresses the importance of uncompromising faith; of the power of this faith; of God's faith; and of faith creating reality. It claims that every true Christian should have such faith. At the same time, it advertises the so-called Theology of Prosperity, which emphasizes the general, and in particular material, welfare of a true believer and his or her physical health. This teaching is also named the Prosperity Gospel or the Health and Wealth Gospel. Also typical of this movement is the importance of Positive Confession, through which the false, fraudulent reality of the Devil - for example, symptoms of a disease - should be overcome through a verbal proclamation of the reality of God's kingdom, a wealthy, healthy and blessed life. Another characteristic feature is the movement's teaching of the power of believers over the Devil and demons. This faith should lead to a victorious life. ${ }^{8}$

4 This term was coined in 1983 by Peter. C. Wagner, a professor of Church Growth at the Fuller Theological Seminary. In: Burgess and VAn Der MaAs, The New Dictionary of Pentecostal and Charismatic Movements, p. 1141.

ANDERSON, An Introduction to Pentecostalism, p. 11.

6 See e.g. "Imparting of Spiritual Gifts" (online), Assemblies of God, 1995-2015, accessed November 2013, available online at http://www.ag.org/top/beliefs/topics/sptlissues_imparting_spiritual gifts.cfm.

7 Kenneth E. Hagin, the leader of this movement, established the biblical school Rhema Bible Training Center in 1974 in Tulsa, OK. This school has dozens of subsidiaries in the whole world and prepares missionaries to carry the message of this faith across the whole world. See also "Hagin, Kenneth E.", in Burgess and VAN DER MAAs, The New Dictionary of Pentecostal and Charismatic Movements, p. 687.

8 "Positive Confession Theology", in Burgess and VAn der MaAs, The New Dictionary of Pentecostal and Charismatic Movements, p. 992-994. 
A fundamental part of the Positive Confession theology is the persuasive power of the spoken word. That means that the phrase "Positive Confession" refers, quite literally, to bringing what we say with our mouth into existence, since faith is a confession. ${ }^{9}$ Man can thus create reality by his word. According to the interpreters of this faith, salvation contains physical healing and universal, most importantly material, blessing. If someone believes that Jesus Christ died for him and rose from the dead, God will bless him not only with the guarantee of an eternal life, but also by healing all his diseases and by providing material welfare.

This teaching was formulated by Essek William Kenyon (1867-1948), the preacher of an independent Baptist church. He was influenced by the teachings of Christian Science, with its protagonist Mary Baker Eddy, and by the teachings of the New Thought Movement, ${ }^{10}$ which draws on the ideas of Phineas P. Quimby. Kenyon hoped that a new formulation of the Christian doctrine would bring a renewal of the Christian faith, since at the beginning of the century there was a substantial rise of movements using similar language in the USA and his chances of succeeding seemed very high.

However, the eventual expansion of this movement, called the Faith Movement, came with K. E. Hagin. It was through his involvement that the movement became Pentecostal in character. Essek William Kenyon himself was not Pentecostal; he even distanced himself from Pentecostalism with a slight disdain.

In 1973, Kenneth E. Hagin founded the biblical school 'Rhema Bible Training College' in Tulsa, Oklahoma. The college now has dozens of branches all over the world and it trains missionaries to bring the message of this faith to the entire world.

The movement itself is anti-ecumenical and anti-denominational in its character. Its aim is to awaken and revitalize faith in Christianity as such and the movement is strictly against the idea of establishing new churches. The goal of the Faith Movement is a revitalization of the church, but the actual result of their doctrines is often division and decline. Due to its criticism of the ecumenical efforts of protestant churches and its anti-denominational shape, it is characterized by a certain lack of unity, which in turn causes its missionary functioning to be somewhat problematic.

Another typical feature of the movement is the absence of a fixed structure. The movement only creates training centres, which serve as centres of distribution and as bases for travelling missionaries of the Faith Movement. That means that its goal is not to establish a new church, since the movement's theology disapproves of church structures, official registration and the institutional shape of church organisations.

\footnotetext{
9 "Positive Confession Theology", in Burgess and Van Der MaAs, The New Dictionary of Pentecostal and Charismatic Movements, p. 992-994.

${ }_{10}$ The philosophy of New Thought has its roots in the teaching of Phineas P. Quimby (1802-1866), who worked with hypnosis and spiritualism. At the same time, he studied various aspects of parapsychology and paranormal phenomena. Mary Baker Patterson Eddy, who formulated the basics of Christian Science in 1862, was probably influenced by his teaching and legacy. See BURGESS and VAN DER MAAs, The New Dictionary of Pentecostal and Charismatic Movements, p. 992.
} 


\section{(3) Free churches, which have emerged through the mission of the Faith Movement}

There are seven important free churches, which have emerged through the mission of the Faith Movement in the Czech Republic. Their importance can be determined by looking at factors such as how many members they have; how long they have been active; their impact on society; and/or whether they have obtained state registration. The only church to have refused state registration is the Centre of Triumphal Faith, while the other observed free churches have acquired it. ${ }^{11}$ Further on, their characteristics will be described and their change of attitude towards the ecumenical movement will be examined.

These seven free churches are: the Word of Life Church (Církev Slovo života), the New Hope Church (Církev Nová naděje), the Church of Living God (Církev živého Boha), the Faith Church (Církev víry), the New Life Church (Církev Nový život), the Oasis Church (Církev Oáza), and the Centre of Triumphal Faith (Triumfální centrum víry). ${ }^{12}$

Some of these fellowships have undergone a gradual change of both teachings and structure, but the reasons for, and the manner of, these changes may differ considerably.

\section{(3.1) The Word of Life Church and its typical denominalization ${ }^{13}$ development}

This chapter will describe the transformation of a mission-based Faith Movement fellowship into a respected denomination, using the example of the development of the Word of Life Church in the Czech Republic.

In 1992, the Swedish Missionary Micael Lundin moved to the Moravia region. He was a follower of Ulf Ekman, the founder of the Word of Life Church in Sweden. Micael Lundin helped the Faith Movement in Brno create a member base. Their assembly was originally called the Heaven Station and it had about 70 people. It was due to Lundin that the main activities of the Faith Movement moved from the Prague Water

"I Date of the registration: the Church of Living God (15. 12. 2007), the New Hope Church (3. 9. 2009), the Word of Life Church (6. 8. 2010), the Faith Church (22. 5. 2012), the New Life Church (25. 10. 2013), the Oasis Church (11. 10. 2014). See also "Data registrace církví a náboženských společností a svazů církví a náboženských společnostî" ["Data of the Registration of Churches and Religious Societies and Organizations of Churches and Religious Societies"], Ministerstvo kultury [Ministry of Culture of the Czech Republic] 2007, Accessed November 2013, available online at http://www.mkcr.cz/cz/cirkve-a-nabozenske-spolecnosti/registrace-a-evidence/data-registrace -cirkvi-a-nabozenskych-spolecnosti-a-svazu-cirkvi-a-nabozenskych-spolecnosti-11263/.

12 The names of the fellowships below have been translated from the Czech language into English. The exceptions are the Oasis Church and the New Life Church, because they do not have official English names on their websites.

${ }_{13}$ During denominalisation, a new religious movement changes into a respected religious institution. The theory of denominalisation describes the typical features of these changes. See ZDENĚK VoJTíšsk, Nová náboženská hnutí a kolektivní násilí [New Religious Movements and Collective Violence], Brno: L. Marek 2009, p. 326-363. 
of Life fellowship to Brno's newly named Word of Life assembly. This fellowship had all the characteristic features of the Faith Movement. ${ }^{14}$

After Micael Lundin's departure in 1996, the assembly found a new leading pastor, Jiří Zdráhal. However, Zdráhal handed his office over to Michal Vaněk in 2003 and in 2006 went on to found the International Christian Fellowship ${ }^{15}$ in Prague. During his time in office, Michal Vaněk tried to strengthen relations with the mother assembly in Uppsala by mission activities through the Alpha Courses, by founding the Christian nursery school and Jan Hus primary school in Brno, by running the online programme TV7, by cooperating with the ICEJ ${ }^{16}$, and with other activities. In 2010, he successfully achieved state registration for the Word of Life fellowship.

All these activities of the present Word of Life show a noticeable shift away from the usual conduct of the Faith Movement, a shift both in doctrine and in practice. The Faith Movement does not usually use mission instruments such as the Alpha Course. It prefers healing campaigns and demonstrations of God's power at its assemblies, where the serving pastor or missionary "distributes" healing by means of holding their arms high or making other gestures towards the crowd. The Word of Life's membership in the Czech Evangelical Alliance and its general ecumenical openness do not fit the profile of the Faith Movement either. On the church's website, in the section "What we believe in"17, there are no elementary teaching articles of the Faith Movement to be found. These facts indicate a shift towards a stance which is acceptable to regular evangelical and Pentecostal teachings and conduct.

This development can also be seen in the life story of Ulf Ekman, the founder of the whole Swedish Faith mission in Europe.

\section{(3.1.1) The life story of Ulf Ekman, the founder of the assembly of the Word of Life, and this mission in Uppsala}

The life story of Ulf Ekman, with its rather surprising outcome, is at the same time a story of the denominalization and institutialization of the whole Faith Movement and its approach to the ecumenical movement.

Ulf Ekman was born in 1950 and converted to Christianity in 1970. After his studies he started his career as a school chaplain of the Swedish Lutheran Church at the University of Uppsala. Through recordings of Kenneth Copeland's sermons, he learned about the teachings of the Faith Movement, which made such a huge impact on him that he decided to study at Hagin's Rhema Bible School. After his return to Sweden, he left his traditional Lutheran mother church, started to preach the Faith Movement message, and founded the Word of Life assembly in Uppsala, as well as a Bible school

${ }^{14}$ See ZdenĚK VojtíšEK, “Cesta Slova života” ["Journey of Word of Life”], Dingir (2/2008): p. 56-59.

15 See also ICF Praha (online), accessed November 2013, available online at http://www.icf-praha.cz.

${ }^{16}$ The International Christian Embassy. See also "Worldwide Branches: The ICEJ's Presence Around the Globe”, Icej.org, accessed March 2016, available online at http://int.icej.org/world/.

17 See also "Čemu věŕíme" ["What do We Believe in"], Slovozivota.cz, accessed March 2015, available online at http://www.slovozivota.cz/o-nas/cemu-verime/. 
and a publishing house. The assembly grew significantly in the following years, and in 1987, Ulf Ekman opened a new prayer room for 4,000 people.

However, the movement did not avoid controversies: they had to deal with the mistrust of state authorities and with scandalization of the new faith by the media, which pointed out its negative influence on the lives of believers. The criticism of the movement in the media grew weaker only in the second half of the 1990s, when the movement slowly began to abandon the radical doctrines of the Faith Movement. In 2000, Ulf Ekman insisted on the importance of good ecumenical relations, which noticeably shook various anti-Catholic and anti-ecumenical attitudes of this movement.

In the Czech Republic, the change of Ekman's views was reflected when the Word of Life declared its affiliation with the Classical Pentecostal Movement on its website ${ }^{18}$ and become a member of the Czech Evangelical Alliance.

Later on, Ulf Ekman shifted his attention to the importance of a good attitude towards Israel. He became a supporter of Christian Zionism, and through Operation Jabotinsky, an organisation that he set up, he helped Russian Jews return to Israel. He was also one of the founders of the study centre for mutual understanding of Jews and Christians in Israel. The biggest surprise for his followers, however, was to come in 2014. Only one year after leaving the pastoral service in his great assembly in Uppsala, he announced his and his wife's conversion to the Roman Catholic Church. In the context of the anti-Catholic and anti-denominational mood, which is more or less typical of the whole Faith Movement, Ekman's decision caused astonishment and turmoil among his followers. This was easily observable on social networks, despite his personal views moving towards such a decision for some time. To some of his followers, making a decision like that in his life was tantamount to denying all that he had built.

Nevertheless, the life story of the protagonist of this movement Ulf Ekman can be seen as a story of the whole Faith Movement. From the radicalism that made Ekman leave his traditional church, to his call for a reorganisation of the church and the foundation of a new, essentially mission-based movement, to a gradual loss of this radicalism, and in the end to a complete abandonment of all radical rhetoric and the problematic teaching articles. Furthermore, this example demonstrates a shift in the general perception of the church: now it is no longer seen as a radical movement that brings renewal through denying traditional values, but instead as an institution, indeed, an institution with a respected history. This has also resulted in the discovery and appreciation of its immensely valuable traditions and their diversity.

Further on, the text will present some similar features other examples of free churches, which emerged through the mission of the Faith Movement in the Czech Republic.

${ }^{18}$ See also P. Kolenčík, Pastorační pohled na hnutí víry [The Faith Movement: A Pastoral Perspective], B.A. thesis, Prague: Catholic Theological Faculty, Charles University 2010, p. 18, note 41. 


\section{(3.2) The New Hope Church and their quest for a new identity}

The New Hope Church consists of the former Reach Out for Christ (thereinafter referred to as R.O.F.C.) assemblies, which were founded by the Faith Movement missionary Steve Ryder in North Moravia, and the Prague assembly of New Beginnings led by Pastor Jerry Lillard. The R.O.F.C. assemblies had some features typical of the Faith Movement, with their emphasis on the spiritual, demonic nature of disease and on healing campaigns. For a long time, Jerry Lillard's assembly was a member of the international organisation of the Faith Christian Fellowship, set up by Kenneth E. Hagin's untimely deceased son-in-law, Buddy Harrison, one of the leading promoters of the Faith Movement.

Nonetheless, despite its obvious origin in the Faith Movement, the freshly established New Hope Church claimed allegiance to one of the oldest Pentecostal churches, the rather classical Church of God. ${ }^{19}$ It joined the Church of God back in 2007, and in an official letter from the 14th of January 2009, the Church of God confirmed that it had issued a pastoral certification to the leaders of the New Hope Church. However, the Basic Document of the New Hope Church states that the teaching doctrines and issues are within the authority of the Collegium of Pastors of the New Hope Church. The New Hope Church also asked the Czech Evangelical Alliance for membership on the 22nd of September 2009. This step is by no means typical for the branches of the Faith Movement. The New Hope Church assemblies do not claim allegiance to the Faith Movement; they make no reference to K. E. Hagin; they have no list of literature written by promoters or adherents of that movement to recommend to their believers; and the structure or designations of the executive functions do not reflect the movement's theology in anything. The New Hope Church does not require knowledge of any important doctrines of the Faith Movement and it declares its affiliation to the classical Pentecostal Movement.

The main reasons for establishing the new church by connecting diverse fellowships was, according to the specialist Mgr. František Fojtík, ${ }^{20}$ a dissatisfaction with the legal form, in which the individual assemblies ran their religious activities, and a search for a wider background.

As was said before, this is how many Faith Movement fellowships work. Their typical feature is the absence of fixed structure: the movement only creates training centres, which act as centres for dissemination of knowledge and as base rooms for traveling missionaries. Its goal is not to establish a new church, since this movement's theology disapproves of church structures, official registrations and any institutional shape of church organisations.

19 The Church of God was founded in 1886 by several Christian fellowships in the v USA. Today it has more than 7 million believers in 170 countries. It is led by Raymond F. Culpepper and the organisation has its headquarters in Cleveland, TN. See also Church of God (online), 2013, accessed March 2015, available online at http://www.churchofgod.org/.

${ }^{20}$ See J. CMíral, "Církev Nová naděje, stručná charakteristika”, zpracováno pro odbor církví MK, ["The Church of New Hope: A Brief Characteristic", an expert report for the Ministry of Culture of the Czech Republic], 2009, p. 1. 
That means that the fellowships that formed the New Hope Church were not satisfied with this system.

The existing system, typical for the Faith Movement, was not pragmatically convenient, since it hindered wider rooting.

As the fellowship that currently makes up the New Hope Church developed, it underwent a shift from theologically radical doctrines to generally more accepted evangelical and Pentecostal teaching and conducts, as well as a transformation of attitudes towards other churches, which is demonstrated, amongst other things, by the application for membership in the Czech Evangelical Alliance. ${ }^{21}$

\section{(3.3) The New Life Church and the founding personality of Mikuláš Törok as a demonstration of the challenge of a single strong personality}

The beginnings of New Life date back to the mid-1980s. The core of the new fellowship consisted of charismatic-oriented members of the Evangelical Brethren Church in Ústí nad Labem in 1994. Under the leadership of Pastor Mikuláš Törok, the assembly started to become similar to the Assembly of Faith in Budapest.

This large assembly is led by Pastor Sándor Németh, who has great influence both in Hungary and abroad. The two most important authorities for this assembly are Kenneth E. Hagin and Derek Prince. After Ulf Ekman's failure, Sándor Németh became a new apostle of the Faith Movement for Europe in the eyes of his followers.

However, the apprentice-based relationship of Pastor Mikuláš Törok, and his New Life Church, with the Assembly of Faith in Budapest weakened significantly around 2005. The New Life Church even started to deny its origin in the missions of the Faith Movement, and declared itself to be a part of the Charismatic Movement.

There are two striking facts about the development of this fellowship. The first one is the deviation of the New Life Church from the European Faith Movement's Apostle Sándor Németh, and the second is that it has tried to join the churches that have emerged from the Charismatic Movement's ranks. ${ }^{22}$

The church's theologically radical doctrines have been adjusted in favour of generally more accepted evangelical and Pentecostal ones, but any greater openness to other churches has been impeded by the centralist leadership, particularly the very strong leadership position of Pastor Mikuláš Török. Török is convinced that ecumenical activities are useless, and doesn't refer to the ecumenical movement at all.

${ }^{21}$ The Evangelical Alliance is a Christian organisation representing evangelical Christians and works as a coordinator of common activity amongst co-operative evangelical churches.

${ }^{22}$ See for example "Základní charakteristika Církve Nový život”, Příloha č. 1 k Návrhu na registraci Církve Nový život ["The Church of New Hope: A Brief Characteristic", an expert report for the Ministry of Culture of the Czech Republic], p. 1. 


\section{(3.4) The Church of Living God as an interesting example of the quest for a non-denominational ideal in the Faith Movement}

The Church of Living God sees itself as a part of the Faith Movement and, unlike the New Hope Church or the New Life Church, it openly claims allegiance to it. It refuses the denominational arrangement and it does not want to be presided over by one leading personality. ${ }^{23}$

The bishops of this church ${ }^{24}$ have only a representative function, without any spiritual significance. This is an interesting solution, considering the heroic character of the founder of the whole movement. The Church of Living God wants to fulfil the ideal of an organisation of the Faith Movement, which forbids the founding of a new denomination. Therefore, it seeks to be a federation-based church.

The Church of Living God openly refers to the legacy of K. E. Hagin, but it has formulated the teachings of the Faith Movement in its own way. In this case, it is not a question of a shift in conduct or an adaptation of the theologically radical doctrines in favour of generally more accepted evangelical and Pentecostal teachings, but instead a change of conduct and presentation of theologically radical doctrines in favour of the Faith Movement itself. Bishop Vít Dan Kolinger claims that the Faith Movement has not been presented in an unbiased way. ${ }^{25}$

The Church also declares that it is not closed and that it develops relations with other churches, but in reality, it seems to only cooperate with assemblies that have close links to the Faith Movement.

Nevertheless, Paragraph 3 of Section 2 of the Articles of the Church of Living God states that the Church may cooperate with, or be incorporated into, another fellowship of churches, e.g. the Evangelical Alliance. ${ }^{26}$

This paragraph serves as evidence of a certain shift and it indicates future possibilities for cooperation with evangelical churches.

${ }^{23}$ See also "Struktura a organizace církve CžB" ["Structure and organisation of the Church of Living God"], Cirkevzivehoboha.cz, 2009, accessed March 2015, available online at http://www .cirkevzivehoboha.cz/o-nas/struktura-cirkve.html.

${ }^{24}$ Vít Dan Kolinger comes from the Roman Catholic Church, where he served actively and which he left after reflecting on his work. He founded the fellowships in Hořovice, in Př́bram and then in Plzeň and České Budějovice. These four fellowships became the foundation for the Church of Living God. The second bishop, Petr Szlaur, comes from the Silesian Evangelical Church of the A.C. After his graduation in evangelical theology in Bratislava he came back to Frýdek-Místek and joined the Apostolic Church. He left with his followers because of his preference for the Faith movement and the ideas of Pastor Miloš Kozohorský. In 2003, he founded an independent church El Šaddaj in Frýdek-Místek. This fellowship joined other fellowships of the Church of Living God in order to get state registration.

${ }^{25}$ See also M. KoŘínek, "Cílem je rozpuštění. Rozhovor s biskupem Církve živého Boha Vítem D. Kolingerem" ["Interview with bishop Vít D. Kolinger of the Church of Living God"], Dingir (2, 2008), p. 58-60.

${ }^{26}$ See also "Církev živého Boha sbor Hradec Králové" ["The Church of Living God, local assembly in Hradec Králové"], CirkevHK.cz, accessed March 2015, available online at http://www.cirkevhk .cz/o-nas/. 


\section{(3.5) The case of the Faith Church as a demonstration of a strong objection to the ecumenical movement}

The Faith Church emerged from the Church of Christian Fellowship as a movement protesting against the rising ecumenical openness. It established itself as an independent fellowship of the Faith Movement after several assemblies had detached and founded their own mission stations. The Faith Church has an important relationship with Sándor Németh, Pastor of the Assembly of Faith in Budapest, and with the founding personality of Pastor Jaroslav Kříz from Banská Bystrica, Slovakia, who has significantly influenced the theology of the Christian Fellowship in Slovakia. As can be seen from the name, the Faith Church fully identified itself with the ideas of the Faith Movement, as well as the Assembly of Faith in Budapest, and with the teachings of Slovak fellowships.

The Faith Church does not show any interest in cooperation with other churches. It takes a suspicious approach to the ecumenical movement and its attitude to the Roman Catholic Church is filled with aversion. It does not show any interest in membership in the Czech Evangelical Alliance, either. The departure of the assemblies and the foundation of the Faith Church can be seen as a textbook example of radicalisation within an established church, in this case the already institutionalized Christian Fellowship, and, among other things, it shows the noticeable shift that the Church of Christian Fellowship has undergone.

\section{(3.6) The apostle commissioning of Festus Nsoha and the Oasis Church as a case of disinterest, due to the strong position of the missionary leader} The Oasis Church was created by a Nigerian missionary, Festus Chikezie Nsoha. Since its very beginning this group has had the typical features of the Faith Movement, indicated by the emphasis on prosperity, success and good health as signs of God's blessing.

The church is an independently acting group and it is not a branch of any international organisation..$^{27}$ The personality of Festus Nsoha is crucial to the movement. The Oasis Church is not subject to any direct management from abroad, nor is it incorporated into any church structures beyond the Czech Republic. ${ }^{28}$ To his followers, Festus Nsoha is an apostle who has received a direct mandate from God for his mission work in the Czech Republic. This leader shows contempt for any ecumenical activities and he makes no references to the ecumenical movement.

That is why, in the case of the Oasis Church, there are no doctrinal shifts coming from positions taken by the Faith Movement, and no changes of attitudes towards other churches. However, the state registration of the Oasis Church was an act of institutionalizing, and thus it may be a promise of its possible future stabilisation in society.

${ }^{27}$ See also D. LuŽNÝ, “Znalecký posudek č. 01/14 v řízení o návrhu na registraci Církve Oáza” [Expert report no. 01/14: Church Oasis expert report for Ministry of Culture], p. 5.

${ }^{28}$ LuŽNÝ, “Znalecký posudek...”, p. 5. 


\section{(3.7) Centre of Triumphal Faith as a case of strong objections to the ecumenical movement, which led to isolation}

The Centre of Triumphal Faith is connected with the activity of Pastor Miloš Kozohorský. This leading pastor founded a Christian Fellowship in Dobřrís 29 in 1990. However, after seven years he handed over the pastorate to his colleague and left to study at Hagin's Rhema Bible School.

After his return to the Czech Republic, he started to preach the Faith Movement's message. He founded a new fellowship, namely the Centre of Triumphal Faith in Prague in 1999 and then in 2002 in Brno and Olomouc. His organisation, the Service of Triumphal Faith, founded in 2001, serves as a centre of distribution of Kenneth Hagin's materials (books, recordings...). ${ }^{30}$ This fellowship is well known in the Czech Republic because of a documentary by Tereza Nvotová "Jesus is normal," which encourages extreme evangelisation on the street, manipulation, and odd religious practices (such as holy laughter, shaking during sermon and others) in this fellowship. The documentary was filmed in 2008 and met with a positive reaction from Czech society. There has been criticism of the movement in mass media.

The Centre of Triumphal Faith sees itself as part of the Faith Movement and K. E. Hagin has exceptional authority in this fellowship. It refuses the denominational arrangement and it is strictly against the idea of establishing new churches.

This fellowship has no interest in establishing ecumenical relationships with other churches; it wants to maintain its own religious practice and thus it has become more and more isolated. Its characterisation by the media also helped drive its isolationism.

\section{(4) Summary}

This paper introduced the diversity of the fellowships of the Faith Movement and offered some examples of the significant shift this movement has undergone. The emergence and development of the seven new free churches in the Czech Republic in the last two or three decades was described. The article has looked into the major features of the process of attitude shift, as well as the change of radical theological doctrine, their methods of mission activities, and the change of their attitude towards other churches and the ecumenical movement. This is also often connected with a change in the structure of these fellowships, which shifts from the leadership of one person to more congregational methods of church management.

\section{Summarisation of the development of free churches:}

The Word of Life Church, the New Hope Church, and the New Life Church do not claim any allegiance to the Faith Movement. The New Life Church has even started to

${ }^{29}$ This fellowship is led by pastor Tomáš Hrubý and his cooperate assistant Robert Klimt today.

${ }^{30}$ His organisation was renamed last year. It is called "Victorious Radio" (translated by author). See also Rádio Vítězství (online), accessed March 2016, available online at http://www.radiovitezstvi .cz/. 
deny its origin in the missions of the Faith Movement. The New Hope Church does not deny the movement's influence as such, but it does not acknowledge the ideas of the Faith Church either.

The Word of Life Church has become open to the ecumenical movement, while the New Hope Church has moved significantly closer to ecumenical activities. There is an obstacle standing in the way of ecumenical activities in the case of the New Life Church, specifically their leading figure.

The Church of Living God, the Faith Church, the Oasis Church and the Centre of Triumphal Faith claim allegiance to the Faith Movement.

The Church of Living God has become partially open, more open than the other fellowships that claim to be part of the Faith Movement.

The Faith Church, the Oasis Church and the Centre of Triumphal Faith protest against ecumenical openness and disdain these activities.

This shift can be observed in some of these free churches - the Faith Movement itself is anti-ecumenical and anti-denominational in its character.

The change of attitude towards ecumenism in some of these free churches, which emerged through the mission of the Faith Movement, means a reconsideration, and possibly even a denial of one of the fundamental Faith Movement doctrines. A shift, which indicates viability and a level of adaptability in this movement in the light of changing conditions, has been described. As a result of abandoning their radical stand points, some of these free churches have been able to accept the ideas of ecumenism and the teaching of evangelical churches.

On the other hand, in the case of the Faith Church (and other small assemblies separated from the Christian Fellowship) the foundation and the growth of new fellowships were initiated through a return to the movement's more radical doctrines.

The Faith Movement aims for a revitalisation of the church, but often the actual result of their doctrines is division and decline. In cases where a stable theology emerges, it is possible to see an improvement in cooperation.

This paper has described a shift towards cooperation with evangelical churches. The article has presented some examples, and named some other fellowships, which have so far been this change and have therefore become increasingly isolated.

\section{REFERENCES}

Anderson, A., An Introduction to Pentecostalism, Cambridge: Cambridge University Press 2007, 318 p.

Burgess, S. M., and E. M. VAn Der MaAs (eds.), The New Dictionary of Pentecostal and Charismatic Movements, revised and expanded edition, Grand Rapids: Zondervan 2002, $1328 \mathrm{p}$.

CMíRAL, J., "Církev Nová naděje, stručná charakteristika”, zpracováno pro odbor církví MK ["The Church of New Hope: A Brief Characteristic", an expert report for the Ministry of Culture of the Czech Republic"], 2009.

Kolenčí́, P., Pastorační pohled na hnutí viry [The Faith Movement: A Pastoral Perspective], B.A. thesis, Praha: Catholic Theological Faculty, Charles University 2010, 62 p. 
Kořínek, M., “Cílem je rozpuštění. Rozhovor s biskupem Církve živého Boha Vítem D. Kolingerem" ["Interview with bishop Vít D. Kolinger of the Church of Living God"], Dingir (2/2008), p. 58-60.

LuŽNÝ, D., “Znalecký posudek č. 01/14 v řízení o návrhu na registraci Církve Oáza” [Expert report no. 01/14: Church Oasis expert report for Ministry of Culture].

VojтíšEK, Z., "Cesta Slova života” [“Journey of Word of Life”], Dingir (2/2008): p. 56-59.

VojTíšEK, Z., Nová náboženská hnutí a kolektivní násilí [New Religious Movements and Collective Violence], Brno: L. Marek 2009, 460 p.

Základní charakteristika Církve Nový život, Příloha č. 1 k Návrhu na registraci Církve Nový život ["The Church of New Hope: A Brief Characteristic", an expert report for the Ministry of Culture of the Czech Republic].

\section{ONLINE SOURCES}

"Čemu věŕme” [“What do We Believe in”], Slovozivota.cz, accessed March 2015, available online at http://www.slovozivota.cz/o-nas/cemu-verime/.

"Data registrace církví a náboženských společností a svazů církví a náboženských společností" ["Data of the Registration of Churches and Religious Societies and Organizations of Churches and Religious Societies"], Ministerstvo kultury [Ministry of Culture of the Czech Republic] 2007, accessed November 2013, available online at http://www.mkcr.cz/cz/cirkve-a-nabozenske-spolecnosti/registrace-a-evidence /data-registrace-cirkvi-a-nabozenskych-spolecnosti-a-svazu-cirkvi-a-nabozenskych -spolecnosti-11263/.

"Imparting of Spiritual Gifts" (online), Assemblies of God, 1995-2015, accessed November 2013, available online at http://www.ag.org/top/beliefs/topics/sptlissues_imparting _spiritual_gifts.cfm.

"Worldwide Branches: The ICEJ's Presence Around the Globe", Icej.org, accessed March 2016, available online at http://int.icej.org/world/.

Church of God (online), 2013, accessed March 2015, available online at http://www .churchofgod.org/.

ICF Praha (online), accessed November 2013, available online at http://www.icf-praha.cz

Rádio Vitězství (online), accessed March 2016, available online at http://www .radiovitezstvi.cz/. 